\title{
Striking the right balance determines TB or not TB
}

\section{Somdeb BoseDasgupta ${ }^{\dagger}$ and Jean Pieters*}

Biozentrum, University of Basel, Basel, Switzerland

\section{Edited by:}

Vishwanath Venketaraman, Western University of Health Sciences, USA

Reviewed by:

Catharine Bosio, National Institutes of Health, USA

Heinrich Korner, Menzies Research Institute Tasmania, Australia

*Correspondence:

Jean Pieters, Biozentrum, University

of Basel, Klingelbergstrasse 50-70,

Basel CH-4056, Switzerland

e-mail: jean.pieters@unibas.ch

\section{${ }^{t}$ Present address:}

Somdeb BoseDasgupta, School of

Biomedical Engineering, Indian

Institute of Technology (BHU),

Varanasi, India
Mycobacterium tuberculosis continues to be one of the most successful pathogens on earth. Upon inhalation of $M$. tuberculosis by a healthy individual, the host immune system will attempt to eliminate these pathogens using a combination of immune defense strategies. These include the recruitment of macrophages and other phagocytes to the site of infection, production of cytokines that enhance the microbicidal capacity of the macrophages, as well as the activation of distinct subsets of leukocytes that work in concert to fight the infection. However, being as successful as it is, M. tuberculosis has evolved numerous strategies to subvert host immunity at virtual every level. As a consequence, one third of the world inhabitants carry $M$. tuberculosis, and tuberculosis continuous to cause disease in more than 8 million people with deadly consequences in well over 1 million patients each year. In this review, we discuss several of the strategies that $M$. tuberculosis employs to circumvent host immunity, as well as describe some of the mechanisms that the host uses to counter such subversive strategies. As for many other infectious diseases, the ultimate outcome is usually defined by the relative strength of the virulence strategies employed by the tubercle bacillus versus the arsenal of immune defense mechanisms of the infected host.

\section{Keywords: Mycobacterium tuberculosis, macrophage, immunity, inflammation}

\section{INTRODUCTION}

Tuberculosis has affected human beings for centuries. Still, onethird of the world's population is infected with Mycobacterium tuberculosis, of which close to 9 million people progress into active disease while the rest remains asymptomatic (1-4). In recent years, the problem of drug resistant strains of $M$. tuberculosis that further limits the possibilities for therapeutic interventions has only added to the global burden of tuberculosis.

The usual route of infection occurs via aerosols containing mycobacteria. These aerosols are released into the environment through coughing by individuals who suffer from active tuberculosis and are inhaled by recipients into the respiratory tract. There, alveolar macrophages phagocytose the bacilli in an attempt to eliminate the pathogen (5-7). However, M. tuberculosis, being an extremely slowly growing microbe, with a generation time of 15-20 h, has evolved elaborate strategies to circumvent the innate antimicrobial response that operates within macrophages, resulting in a long-term cohabitation of M. tuberculosis with their host cells. Once inside the host, $M$. tuberculosis can meet several fates: the bacteria can be killed and eliminated, they can survive and proliferate, resulting in active disease, or the bacilli stop growing but reside within the host in a latent state; as a result of the latter, many individuals harbor life-long infections of slowly growing or even dormant bacteria that have also the potential to become reactivated; whether active tuberculosis results from reactivation or de novo secondary infections remains unclear in many cases (8-12).

Once within the host, $M$. tuberculosis excels at circumventing macrophage immune defense mechanisms and interferes at different levels with the generation of an effective acquired immune response, largely through the modulation of and interference with cytokine-mediated immune activation mechanisms $(1,13,14)$.
However, other than the mycobacterial load itself, also the resulting immune activation that aims to control the infection can contribute to the pathology associated with tuberculosis thereby resulting in the development of active disease both at the site of infection, in the lungs, and also within other organs following mycobacterial dissemination (15-17).

Progression of an M. tuberculosis infection usually includes an initial innate phase followed by an adaptive immune response that can progress into a chronic state $(2,18-20)$. In this article, the capacity of mycobacteria to evade the microbicidal activity of macrophages as well as the response of the host through innate and adaptive immune responses will be reviewed, with a focus on those issues that determine whether the balance tips in favor of the pathogen or the host.

\section{ENTRY OF MYCOBACTERIA INTO MACROPHAGES}

The primary cells in the respiratory tract that are in charge of host defense are the alveolar macrophages, and due to the presence of a diverse number of ligands on the mycobacterial surface, a large repertoire of macrophage receptors can be involved in pathogen recognition and internalization. Such receptors include complement receptors, mannose receptors, scavenger receptors, and C-type lectins such as DC-SIGN, pattern recognition receptors, and surfactant protein receptors. Any of these receptors can lead to uptake through receptor-mediated phagocytosis by recognizing molecules on the mycobacterial surface (21-28). Several lines of evidence implicate the so-called "mammalian cell entry" proteins (Mce 1-4) expressed by mycobacteria in the internalization of mycobacteria into phagocytes $(29,30)$. Mce proteins contain a well characterized Arg-Gly-Asp (RDG) motif that is responsible for binding to integrins at the mammalian cell surface 
(31); also, the Mce proteins have been suggested to represent ABC transporters possibly involved in lipid import $(32,33)$. The precise mode of action of these Mce proteins remains unclear, as $M$. tuberculosis strains lacking Mce 1 are hypervirulent in mice whereas disruption of Mce 2-4 results in attenuation (34-36). One other key component regulating mycobacterial entry is plasma membrane resident cholesterol, whose depletion from the macrophage membrane prevents bacterial entry (37). Cholesterol could serve to directly provide entry of mycobacteria via the plasma membrane or allow the stable expression of receptor and/or signaling molecules that assist mycobacterial entry $(38,39)$.

Another class of molecules, essential for microbial recognition in both macrophages and dendritic cells, are Toll-like receptors (TLRs). The cytoplasmic domain of TLRs is linked to adaptor proteins including not only myeloid differentiation primary response gene (88) product $(\mathrm{MyD} 88)$ but also MyD88 adapterlike (Mal), TIR (Toll/Ill receptor)-domain-containing adapterinducing interferon- $\beta$ (TRIF) and TLR 4 adaptor protein (TRAM) in case of TLR4. Those adaptors then recruit interleukin-1 receptor-associated kinase (IRAK) 2 and 4, leading to the activation of nuclear factor 'kappa-light-chain-enhancer' of activated B-cells (NFkB) (40-42). Mycobacterial peptidoglycans, lipopeptides, and mycobacterial DNA are recognized by TLR2, 4, and 9, respectively (43). TLR activation has numerous consequences, including the production of inflammatory mediators, the regulation of phagocytosis, as well as connecting the phagosomal pathway with autophagosomes thereby inducing rapid mycobacterial killing (44-49). Whereas a functional connection between phagocytosis and autophagosome formation has been mainly demonstrated using model particles (48). It has also been shown that macrophages harboring $M$. tuberculosis eliminate the pathogen via autophagy (50). One additional advantage of TLR-mediated activation of phagocytosis and autophagosome formation may be a more efficient regulation of antigen processing and presentation by infected macrophages (47). Also, in human macrophages, TLR activation was shown to result in upregulation of a vitamin D-induced antimicrobial pathway that inhibits the growth of M. tuberculosis $(51,52)$.

\section{BALANCING SURVIVAL STRATEGIES EMPLOYED BY M. TUBERCULOSIS AGAINST HOST DEFENSE STRATEGIES}

Following receptor recognition and phagocytosis of $M$. tuberculosis by alveolar macrophages, a plethora of reactions are initiated by both the host and the mycobacteria, which together determine the outcome of the infection. In general, macrophages tend to destroy anything that is phagocytosed; however, pathogenic mycobacteria have developed an elaborate range of strategies to combat the bactericidal milieu encountered upon ingestion.

\section{BLOCKING THE DELIVERY OF M. TUBERCULOSIS TO LYSOSOMES}

Several host factors are involved in the modulation of intracellular trafficking of mycobacteria within macrophages. One of these is the protein coronin 1 (also known as P57 or TACO, for tryptophan aspartate containing coat protein) that is present at the cell cortex of macrophages, and is actively recruited and retained at the cytosolic face of nascent mycobacteria-containing phagosomes $(7,8,37,53)$. Coronin 1-dependent blockage of phagosome maturation occurs through activation of the $\mathrm{Ca} 2+/$ calcineurin pathway, possibly involving dephosphorylation of molecules normally involved in the regulation of intracellular trafficking of phagosomal cargo (54-59). The exact mechanisms of coronin 1 retention at the mycobacterial phagosome remain to be determined and may involve the enzyme lipoamide dehydrogenase that is secreted by mycobacteria and is also known to be involved in resisting the toxic effects of nitrogen intermediates generated by host cells $(60,61)$. In line with an important role for calcineurin in promoting mycobacterial survival, it was shown that calcineurin inhibitors such as cyclosporin A and FK506 can induce mycobacterial transfer to lysosomes and their killing $(54,55,62)$. Whether or not blocking of this pathway may be useful for the treatment of mycobacterial infections is unclear, since both calcineurin and coronin 1 are important molecules involved in T-cell homeostasis $(56,59,63,64)$.

Mycobacteria-containing phagosomes are known to continuously shed off phosphatidylinositol-3-phosphate (PI3P), a key phosphoinositide known to regulate the phagosomal acquisition of lysosomal constituents (65). Also, dephosphorylation of the vacuolar protein sorting protein $33 \mathrm{~B}$ prevents membrane fusion events that are crucial for phagosome maturation (66). It is quite possible that different host factors are being hijacked at distinct phases of the infection process, and future work may shed further light on the precise kinetics of the above mentioned processes.

\section{ROLE OF MYCOBACTERIAL VIRULENCE FACTORS IN PREVENTING PHAGOSOME-LYSOSOME FUSION}

In the course of the co-evolution with their host cell, the macrophage, M. tuberculosis has built up a large arsenal of virulence factors that can interfere with host immune functions at different levels. The virulence repertoire of mycobacteria comprises distinct kinases, phosphatases, metalloproteinases, and pore forming proteins, which together constitute a potent infectious challenge.

One of these virulence factors is the exported repeated protein (Erp) that is required for intracellular replication of pathogenic mycobacteria (67). Erp proteins have three domains, where the amino terminus harbors a signal sequence, a central variable domain containing PGLTS repeats, and a proline-alanine rich Cterminus. Erp is important to maintain the cell wall integrity of mycobacteria through the riboflavin metabolism pathway and is required for its survival both in macrophages and in vivo $(68,69)$.

Another mycobacterial factor, the eukaryote-like serine/ threonine protein kinase protein kinase $\mathrm{G}(\mathrm{PknG})$, is released by mycobacteria into the host cytosol, thereby blocking phagosomelysosome fusion $(39,70,71)$. As a consequence, mycobacteria lacking PknG are rapidly transferred to lysosomes and degraded (70, 72-75). Interestingly, although highly homologous to eukaryotic serine/threonine protein kinases, $\mathrm{PknG}$ contains a binding pocket for substrates that is shaped by a unique set of amino acid side chains that are not found in any human kinase. Therefore, $\mathrm{PknG}$ is well amenable to specific inhibition without the risk of targeting host kinases, thereby possibly allowing the inhibition of intracellular replication of pathogenic mycobacteria without adverse effects on host cells $(73,76,77)$. 
Within macrophages, mycobacteria also release a phosphatase, called secreted acid phosphatase of M. tuberculosis (SapM), that hydrolyzes phosphatidyl inositol 3 phosphate (PI3P), which, as mentioned above, is involved in regulating phagosome-lysosome fusion. As a consequence of depleting PI3P locally, mycobacterial SapM contributes to the inhibition of phagosome maturation and thereby intracellular mycobacterial survival $(78,79)$. Furthermore, a putative zinc-dependent metalloprotease ( $\mathrm{Zmp1}$ ) released by mycobacteria interferes with phagolysosome biogenesis by interfering with caspase 1-dependent activation. Activated caspase 1 is known to cleave pro-interleukin- $1 \beta$ in order to generate active interleukin- $1 \beta$ and activating the inflammasome complex $(80,81)$. The absence of Zmp1 suppresses this activation and thereby promotes phagosome-lysosome fusion and elimination of mycobacteria (82). Also, the enhanced intracellular survival (Eis) protein is known to prevent natural killer (NK) cell-dependent reactive oxygen species (ROS) generation via its aminoglycosyl aminotransferase activity (83). Eis protein dampens tumor necrosis factor- $\alpha(\mathrm{TNF} \alpha)$ and interleukin-10 production thereby preventing macrophage activation. Macrophage activation through TNF $\alpha$ or interferon- $\gamma$ results in phagosome-lysosome fusion. Eis protein inhibits the generation of ROS in the cell and thereby prevents the onset of macrophage activation and autophagy (84).

Finally, although not directly involved in the modulation of phagosome-lysosome fusion, the type VII secretion system encoded by the RD1 locus is known to produce and secrete the early secretory antigenic target (ESAT) 6 and culture filtrate protein (CFP) 10, which are key components for promoting cytosolic escape of mycobacteria (85-88). The ESX-1 gene cluster exhibits higher expression when mycobacteria encounter a reduced $\mathrm{pH}$, and perhaps the ESX-1 system is therefore a mechanism allowing the cytosolic escape of those mycobacteria that may have been transferred to the lysosome (89-92).

\section{MACROPHAGE ACTIVATION AS A MECHANISM TO COUNTERACT MYCOBACTERIAL INFECTIONS}

One of the consequences of infection is the activation of innate immune responses through the release of macrophage-activating molecules such as various cytokines including interferon- $\gamma$ (9397). Activated macrophages then modulate intracellular trafficking of mycobacteria and promote phagolysosome formation resulting in mycobacterial destruction $(98,99)$. Macrophage activation allows the replenishment of phosphoinositides at mycobacteriacontaining vesicles and thereby promotes the exchange of Rab5 by Rab7, which is crucial to its fusion with the lysosome (79). Also, the natural resistance-associated macrophage protein 1 (Nramp1), a metal ion transporter that scavenges metal ions from the microbecontaining vesicles (100-103), is modulated by macrophageactivating cytokines such as interferon- $\gamma$ (104). Defects in Nramp production lead to susceptibility to mycobacterial infections (103, 105, 106).

A recent study shows that inflammatory stimuli such as induced by interferon- $\gamma$ or $\mathrm{TNF} \alpha$ result in the phosphorylation of the protein coronin 1 , which as described above is crucial to allow mycobacterial survival in non-activated macrophages. Activationinduced phosphorylation of coronin 1 results in its delocalization from the cell cortex to cytoplasmic punctae, thereby reprograming the macrophage endocytic pathway from receptormediated phagocytosis to macropinocytosis (107). Interestingly, relocated coronin 1 activates phosphatidylinositol (PI)-3-kinase, which is required for an early burst of PIP3 that is known to be essential for membrane ruffle formation and induction of macropinocytosis (107-110).

Macropinocytic uptake of mycobacteria along with the upregulation of the interferon- $\gamma$ response genes plays a critical role in pathogen elimination (111-113). These interferon- $\gamma$-induced genes include the LPS-stimulated RAW 264.7 macrophage protein 47 homolog (LRG-47), also known as Irgm1 (114-116), as well as a series of guanylate-binding proteins (GBPs) that are involved in the activation of diverse host defense mechanisms, including activation of the phagocyte oxidase, generation of antimicrobial peptides, and induction of autophagy $(117,118)$. Interestingly, recent work suggests that Irgm 1/LRG-47 fails to associate with mycobacterial phagosomes (119) and that deficiency of Irgm1/LRG-47 results in an interferon- $\gamma$-dependent collapse of the lymphomyeloid system, causing general susceptibility to pathogens (120-122). Thus, these immunity-related GTPases may have a rather broad function in shaping the immune system as also exemplified by recent work implicating Irgm1/LRG-47 in hematopoietic stem cell proliferation $(116,123)$.

\section{KEY HOST DEFENSE FACTORS INVOLVED IN THE ELIMINATION OF MYCOBACTERIA UPON MACROPHAGE ACTIVATION}

Once in the phagosome, a number of antibacterial molecules directly threaten mycobacterial viability. Among these, reactive oxygen intermediates in the form of hydrogen peroxide are generated by macrophages via the oxidative burst, and effectively limits mycobacterial growth within macrophages $(124,125)$. Interestingly, vitamin $\mathrm{C}$ along with the antibiotic isoniazid was recently shown to effectively kill extreme and total drug resistant $M$. tuberculosis through the induction of ROS (126).

Reactive nitrogen intermediates are generated by cytokineactivated macrophages through inducible nitric oxide synthetase using L-arginine as the substrate $(127,128)$. Upon mycobacterial infection, mycobacteria upregulate macrophage arginase, which then catalyzes L-arginine to L-ornithine and urea and thereby prevents nitric oxide generation (129). In addition, the mycobacterial proteasome is also involved in resistance against nitric oxide stress $(130,131)$, and specific inhibition of mycobacterial proteasomes may be useful to prevent mycobacterial growth within macrophages (132).

As mentioned above, induction of autophagy that is involved in the clearance of many intracellular pathogens is also used by infected host cells to eliminate M. tuberculosis $(133,134)$. Shuttling of M. tuberculosis into autophagosomes can occur via a ubiquitinmediated pathway; recent work has implicated a ubiquitin ligase termed parkin, mutations of which are associated with increased risks for Parkinson disease, in the transfer of M. tuberculosis as well as other pathogens to the autophagic pathway (135).

\section{FORMATION OF GRANULOMAS}

The survival strategies of mycobacteria and the innate and adaptive immune response elicited to restrict mycobacterial survival and growth come together in a dynamic combat zone called 
the granuloma $(8,136)$. Within granulomas, the host attempts to control mycobacterial dissemination, while at the same time propagation of mycobacteria can occur (107, 137-139). Within granulomas, macrophages harboring viable bacteria are being surrounded by a layer of activated macrophages that ensure mycobacterial elimination. These activated macrophages can process and present mycobacterial antigens to an outer layer of $\mathrm{T}$ lymphocytes upon which these T-cells secrete cytokines and chemokines that keeps the macrophages in an activated state $(5,13,20)$. Thus, granuloma formation represents a delicate balance that is easily disturbed either by enhanced virulence of the mycobacteria or a deteriorating host immunity, such as under immunocompromised conditions (140). New research into the biology of granulomas using different model systems may allow a better understanding of these important structures involved in balancing the host versus the pathogen. TNF- $\alpha$ is essential for the formation and maintenance of granulomas, promoting the release of chemokines, cytokines, and adhesion molecules, which in turn activates and recruit neutrophils required for enhancing the microbicidal activity of macrophages. As a result, anti-TNF- $\alpha$ therapy for the treatment of inflammatory conditions can result in the reactivation of granulomatous infections by inhibiting microbicidal activity $(141,142)$.

\section{CELLULAR IMMUNE RESPONSE AGAINST MYCOBACTERIA - ROLE OF LEUKOCYTE SUBSETS AND CYTOKINES}

Phagocytes play a key role in initiating and directing adaptive immune responses through antigen presentation and expression of co-stimulatory signals and cytokines. However, other leukocyte subsets are also important in the host defense against $M$. tuberculosis $(9,143)$. These other components of innate immunity include neutrophils as well as NK cells. Neutrophils are not only abundant but also the first cells to arrive at the replicating mycobacteria loci and play an important role in controlling the bacterial load, yet at the same time may be involved in the induction of tissue damage (144-146). NK cells are known to directly lyse the mycobacteria or mycobacteria-harboring macrophages (147). At initial stages of infection NK cells can induce macrophage activation resulting in mycobacterial killing as well as induce macrophage apoptosis also resulting in the destruction of the intracellularly residing bacteria $(148,149)$.

Since mycobacteria reside in vacuoles within macrophages, major histocompatibility complex (MHC) class II presentation of mycobacterial antigens to CD4 $+\mathrm{T}$-cells is an obvious outcome (1, 150-152); indeed, depletion of CD4+ T-cells from the periphery results in acute mycobacterial pathogenesis (153-155). However, the presence of a pool of M. tuberculosis in the cytosol of infected macrophages as well as MHC class I-mediated antigen presentation from phagosomes may also result in the activation of CD8+ T-cells via MHC class I-mediated presentation (91, 156-159). Furthermore, CD1- and MHC class I-restricted CD8+ T-cells can induce perforin/granulysin-mediated lysis of mycobacteria within infected macrophages and dendritic cells (160). Finally, the socalled $\gamma / \delta$ T-cells that represent a small subset of T-cells expressing a $\gamma$ - and $\delta$-chain instead of the conventional $\alpha$ - and $\beta$-chain of the T-cell receptor (161-163) are also important for the control of $M$. tuberculosis within an infected host (164). These $\gamma / \delta$ T-cells appear to recognize specific mycobacterial protein and peptide antigens in an MHC-unrestricted manner (164-168). The precise contribution of $\gamma \delta$ T-cells to mycobacterial immunity is still unclear, but given the importance of mycobacterial lipids in the virulence of infection these cells might in fact constitute an important arm of the immune response.

An important function of CD4+ T-cells is the production of cytokines in order to activate macrophages, that in turn upregulate both the capacity to internalize and destroy mycobacteria (107, 153, 169). The predominant pro-inflammatory cytokines that are crucial to counteract mycobacterial infection include interferon- $\gamma$, TNF $\alpha$, interleukin-2, and interleukin-12. Mainly, CD4+ T-cells, and also CD8 + T-cells, NK cells, and infected macrophages all produce interferon- $\gamma$, which results in the augmentation of antigen processing and presentation $(111,170,171)$. Additionally, cytokine activation increases mycobacterial uptake and elimination through upregulation of macropinocytosis and autophagosome formation $(107,133,134,172)$. The central role for interferon- $\gamma$ in the control of mycobacterial infections is also illustrated by the high susceptibility of both mice and human beings bearing mutations in genes coding for the interferon- $\gamma$ receptor (173-175).

Another important cytokine involved in mycobacterial control is $\mathrm{TNF} \alpha$, which is secreted mainly by macrophages and dendritic cells. Similar to interferon- $\gamma$, mice lacking TNF $\alpha$ or its receptor are susceptible to mycobacterial infection $(176,177)$. TNF $\alpha$ plays an important role in granuloma formation and parasite dissemination from the granuloma (178).

The cytokine interleukin-2 that is essential for peripheral T-cell survival, alone or in synergy with other cytokines, is also important to control mycobacterial infection $(179,180)$. Also, phagocytosis of mycobacteria triggers the production of interleukin-12, which results in the induction of interferon- $\gamma$ in an autocrine and paracrine fashion (181-185). Furthermore, in macrophages, the cytokine interleukin-4 induces a so-called alternative activation of macrophages, resulting in the upregulation of arginase 1 and suppressor of cytokine signaling (SOCS) 3 like proteins (186). Increased expression of interleukin- 4 can result in reactivation of latent tuberculosis $(187,188)$ illustrating the complex role of interleukin-4 during mycobacterial infections.

Recognition of the mycobacterial cell wall component lipoarabinomannan by macrophages as well as its phagocytosis results in the secretion of the anti-inflammatory cytokine, interleukin-10 (189) which, in turn, dampens the expression of pro-inflammatory cytokines interferon- $\gamma, \mathrm{TNF} \alpha$, and interleukin-12 (190-194). Hence, interleukin-10 interferes with the host defense against tuberculosis, which is in line with the observed lower bacterial burden in mice lacking interleukin-10 (195). Lipoarabinomannan is also known to induce transforming growth factor (TGF)- $\beta$ production by macrophage and dendritic cells, thereby counteracting macrophage activation as well as protective immunity against tuberculosis (189, 196-198). These various anti-inflammatory cytokines are expressed to counterbalance the activity of proinflammatory cytokines during mycobacterial infection; however, the relative role of pro- and anti-inflammatory cytokines in the disease process remains unclear, and may change depending on either the time course or the precise location of the infection $(199,200)$. 


\section{CONCLUDING REMARIKS}

The response of the host to mycobacterial infection is complex and multifactorial involving many different immune components. Mycobacteria excel at subverting immune responses through a variety of mechanisms both by involving mycobacterial virulence factors and by hijacking host defense mechanisms. The immune response of the host, resulting in macrophage activation, alters the functionality of these host factors in order to enable pathogen elimination. The continuous tug of war between invading mycobacteria and host immunity finally determines the disease outcome. Future studies combining present day technical advances with the study of suitable host models may help to further unravel the intricate virulence mechanisms of this immensely successful pathogen.

\section{ACKNOWLEDGMENTS}

We thank Stefan Dexler and Michael Stiess for critical reading and comments. This work was supported by the Swiss National Science Foundation, the Canton of Basel, the Optimus Foundation, and the Novartis Research Foundation. Somdeb BoseDasgupta was a recipient of an EMBO Long Term Fellowship.

\section{REFERENCES}

1. Kaufmann SH. How can immunology contribute to the control of tuberculosis? Nat Rev Immunol (2001) 1:20-30. doi:10.1038/35095558

2. Russell DG, Barry CE III, Flynn JL. Tuberculosis: what we don't know can, and does, hurt us. Science (2010) 328:852-6. doi:10.1126/science.1184784

3. O'Garra A, Redford PS, McNab FW, Bloom CI, Wilkinson RJ, Berry MP. The immune response in tuberculosis. Annu Rev Immunol (2013) 31:475-527. doi:10.1146/annurev-immunol-032712-095939

4. WHO and 104, F.S.N. (2014). Available form http://www.who.int/mediacentre/ factsheets/fs104/en/

5. Kaufmann SH. Immunity to intracellular bacteria. Annu Rev Immunol (1993) 11:129-63. doi:10.1146/annurev.iy.11.040193.001021

6. Russell DG. Mycobacterium tuberculosis: here today, and here tomorrow. Nat Rev Mol Cell Biol (2001) 2:569-77. doi:10.1038/35085034

7. Pieters J. Mycobacterium tuberculosis and the macrophage: maintaining a balance. Cell Host Microbe (2008) 3:399-407. doi:10.1016/j.chom.2008.05.006

8. Cosma CL, Sherman DR, Ramakrishnan L. The secret lives of the pathogenic mycobacteria. Annu Rev Microbiol (2003) 57:641-76. doi:10.1146/annurev. micro.57.030502.091033

9. Smith I. Mycobacterium tuberculosis pathogenesis and molecular determinants of virulence. Clin Microbiol Rev (2003) 16:463-96. doi:10.1128/CMR.16.3.463496.2003

10. Gideon HP, Flynn JL. Latent tuberculosis: what the host "sees"? Immunol Res (2011) 50:202-12. doi:10.1007/s12026-011-8229-7

11. Ernst JD. The immunological life cycle of tuberculosis. Nat Rev Immunol (2012) 12:581-91. doi:10.1038/nri3259

12. Kaufmann SH. Tuberculosis vaccines: time to think about the next generation. Semin Immunol (2013) 25:172-81. doi:10.1016/j.smim.2013.04.006

13. Chan J, Flynn J. The immunological aspects of latency in tuberculosis. Clin Immunol (2004) 110:2-12. doi:10.1016/S1521-6616(03)00210-9

14. Nguyen L, Pieters J. Mycobacterial subversion of chemotherapeutic reagents and host defense tactics: challenges in tuberculosis drug development. Annu Rev Pharmacol Toxicol (2009) 49:427-53. doi:10.1146/annurev-pharmtox061008-103123

15. Flynn JL, Chan J, Lin PL. Macrophages and control of granulomatous inflammation in tuberculosis. Mucosal Immunol (2011) 4:271-8. doi:10.1038/mi. 2011.14

16. Lawn SD, Zumla AI. Tuberculosis. Lancet (2011) 378:57-72. doi:10.1016/ S0140-6736(10)62173-3

17. Dorhoi A, Iannaccone M, Maertzdorf J, Nouailles G, Weiner J III, Kaufmann SH. Reverse translation in tuberculosis: neutrophils provide clues for understanding development of active disease. Front Immunol (2014) 5:36. doi:10.3389/fimmu.2014.00036
18. Serbina NV, Flynn JL. CD8(+) T cells participate in the memory immune response to Mycobacterium tuberculosis. Infect Immun (2001) 69:4320-8. doi:10.1128/IAI.69.7.4320-4328.2001

19. Kaufmann SH, Cole ST, Mizrahi V, Rubin E, Nathan C. Mycobacterium tuberculosis and the host response. J Exp Med (2005) 201:1693-7. doi:10.1084/jem. 20050842

20. Pieters J. Manipulation of the macrophage response by pathogenic mycobacteria. In: Kaufmann EA, Rubin E, editors. Handbook of Tuberculosis: Molecular Biology and Biochemistry. Wiley-VCH (2008). p. 89-115.

21. Weikert LF, Edwards K, Chroneos ZC, Hager C, Hoffman L, Shepherd VL. SPA enhances uptake of bacillus Calmette-Guerin by macrophages through a specific SP-A receptor. Am J Physiol (1997) 272:L989-95.

22. Ernst JD. Macrophage receptors for Mycobacterium tuberculosis. Infect Immun (1998) 66:1277-81.

23. Aderem A, Underhill DM. Mechanisms of phagocytosis in macrophages. Annu Rev Immunol (1999) 17:593-623. doi:10.1146/annurev.immunol.17.1.593

24. Tailleux L, Pham-Thi N, Bergeron-Lafaurie A, Herrmann JL, Charles P, Schwartz O, et al. DC-SIGN induction in alveolar macrophages defines privileged target host cells for mycobacteria in patients with tuberculosis. PLoS Med (2005) 2:e381. doi:10.1371/journal.pmed.0020381

25. Driessen NN, Ummels R, Maaskant JJ, Gurcha SS, Besra GS, Ainge GD, et al. Role of phosphatidylinositol mannosides in the interaction between mycobacteria and DC-SIGN. Infect Immun (2009) 77:4538-47. doi:10.1128/ IAI.01256-08

26. Ishikawa E, Ishikawa T, Morita YS, Toyonaga K, Yamada H, Takeuchi O, et al. Direct recognition of the mycobacterial glycolipid, trehalose dimycolate, by Ctype lectin Mincle. J Exp Med (2009) 206:2879-88. doi:10.1084/jem.20091750

27. Fukuda T, Matsumura T, Ato M, Hamasaki M, Nishiuchi Y, Murakami Y, et al. Critical roles for lipomannan and lipoarabinomannan in cell wall integrity of mycobacteria and pathogenesis of tuberculosis. MBio (2013) 4:e472-412. doi:10.1128/mBio.00472-12

28. Hossain MM, Norazmi MN. Pattern recognition receptors and cytokines in Mycobacterium tuberculosis infection - the double-edged sword? Biomed Res Int (2013) 2013:179174. doi:10.1155/2013/179174

29. Arruda S, Bomfim G, Knights R, Huima-Byron T, Riley LW. Cloning of an M. tuberculosis DNA fragment associated with entry and survival inside cells. Science (1993) 261:1454-7. doi:10.1126/science.8367727

30. Riley LW. Determinants of cell entry and intracellular survival of Mycobacterium tuberculosis. Trends Microbiol (1995) 3:27-31. doi:10.1016/S0966$842 X(00) 88865-4$

31. Ruoslahti E. RGD and other recognition sequences for integrins. Annu Rev Cell Dev Biol (1996) 12:697-715. doi:10.1146/annurev.cellbio.12.1.697

32. Casali N, Riley LW. A phylogenomic analysis of the actinomycetales mce operons. BMC Genomics (2007) 8:60. doi:10.1186/1471-2164-8-60

33. Pandey AK, Sassetti CM. Mycobacterial persistence requires the utilization of host cholesterol. Proc Natl Acad Sci U S A (2008) 105:4376-80. doi:10.1073/ pnas.0711159105

34. Shimono N, Morici L, Casali N, Cantrell S, Sidders B, Ehrt S, et al. Hypervirulent mutant of Mycobacterium tuberculosis resulting from disruption of the mcel operon. Proc Natl Acad Sci U S A (2003) 100:15918-23. doi:10.1073/pnas. 2433882100

35. Senaratne RH, Sidders B, Sequeira P, Saunders G, Dunphy K, Marjanovic O, et al. Mycobacterium tuberculosis strains disrupted in mce 3 and mce4 operons are attenuated in mice. J Med Microbiol (2008) 57:164-70. doi:10.1099/jmm.0. 47454-0

36. Marjanovic O, Miyata T, Goodridge A, Kendall LV, Riley LW. Mce2 operon mutant strain of Mycobacterium tuberculosis is attenuated in C57BL/6 mice. Tuberculosis (2010) 90:50-6. doi:10.1016/j.tube.2009.10.004

37. Gatfield J, Pieters J. Essential role for cholesterol in entry of mycobacteria into macrophages. Science (2000) 288:1647-50. doi:10.1126/science.288.5471.1647

38. Schlesinger LS. Entry of Mycobacterium tuberculosis into mononuclear phagocytes. Curr Top Microbiol Immunol (1996) 215:71-96.

39. Nguyen L, Pieters J. The Trojan horse: survival tactics of pathogenic mycobacteria in macrophages. Trends Cell Biol (2005) 15:269-76. doi:10.1016/j.tcb.2005. 03.009

40. Merdzhitov R, Janeway C. An ancient system of host defense. Curr Opin Immunol (1998) 10:12-5. doi:10.1016/S0952-7915(98)80024-1

41. Takeda K, Akira S. Toll-like receptors in innate immunity. Int Immunol (2005) 17:1-14. doi:10.1093/intimm/dxh186 
42. Akira S, Uematsu S, Takeuchi O. Pathogen recognition and innate immunity. Cell (2006) 124:783-801. doi:10.1016/j.cell.2006.02.015

43. Yoshimura A, Lien E, Ingalls RR, Tuomanen E, Dziarski R, Golenbock D. Cutting edge: recognition of Gram-positive bacterial cell wall components by the innate immune system occurs via toll-like receptor 2. J Immunol (1999) 163:1-5.

44. Brightbill HD, Libraty DH, Krutzik SR, Yang RB, Belisle JT, Bleharski JR, et al. Host defense mechanisms triggered by microbial lipoproteins through toll-like receptors. Science (1999) 285:732-6. doi:10.1126/science.285. 5428.732

45. Underhill DM, Ozinsky A, Hajjar AM, Stevens A, Wilson CB, Bassetti M, et al. The toll-like receptor 2 is recruited to macrophage phagosomes and discriminates between pathogens. Nature (1999) 401:811-5. doi:10.1038/44605

46. Doyle SE, O'Connell RM, Miranda GA, Vaidya SA, Chow EK, Liu PT, et al. Toll-like receptors induce a phagocytic gene program through p38. J Exp Med (2004) 199:81-90. doi:10.1084/jem.20031237

47. Blander JM. Coupling toll-like receptor signaling with phagocytosis: potentiation of antigen presentation. Trends Immunol (2007) 28:19-25. doi:10.1016/j. it.2006.11.001

48. Sanjuan MA, Dillon CP, Tait SW, Moshiach S, Dorsey F, Connell S, et al. Toll-like receptor signalling in macrophages links the autophagy pathway to phagocytosis. Nature (2007) 450:1253-7. doi:10.1038/nature06421

49. Redlich S, Ribes S, Schutze S, Eiffert H, Nau R. Toll-like receptor stimulation increases phagocytosis of Cryptococcus neoformans by microglial cells. J Neuroinflammation (2013) 10:71. doi:10.1186/1742-2094-10-71

50. Singh SB, Davis AS, Taylor GA, Deretic V. Human IRGM induces autophagy to eliminate intracellular mycobacteria. Science (2006) 313:1438-41. doi:10. $1126 /$ science. 1129577

51. Liu PT, Stenger S, Li H, Wenzel L, Tan BH, Krutzik SR, et al. Toll-like receptor triggering of a vitamin D-mediated human antimicrobial response. Science (2006) 311:1770-3. doi:10.1126/science.1123933

52. Zasloff M. Fighting infections with vitamin D. Nat Med (2006) 12:388-90. doi:10.1038/nm0406-388

53. Ferrari G, Langen H, Naito M, Pieters J. A coat protein on phagosomes involved in the intracellular survival of mycobacteria. Cell (1999) 97:435-47. doi:10.1016/S0092-8674(00)80754-0

54. Jayachandran R, Sundaramurthy V, Combaluzier B, Mueller P, Korf H, Huygen $\mathrm{K}$, et al. Survival of mycobacteria in macrophages is mediated by coronin 1-dependent activation of calcineurin. Cell (2007) 130:37-50. doi:10.1016/ j.cell.2007.04.043

55. Trimble WS, Grinstein S. TB or not TB: calcium regulation in mycobacterial survival. Cell (2007) 130:12-4. doi:10.1016/j.cell.2007.06.039

56. Mueller P, Massner J, Jayachandran R, Combaluzier B, Albrecht I, Gatfield $\mathrm{J}$, et al. Regulation of $\mathrm{T}$ cell survival through coronin-1-mediated generation of inositol-1,4,5-trisphosphate and calcium mobilization after $\mathrm{T}$ cell receptor triggering. Nat Immunol (2008) 9:424-31. doi:10.1038/ni1570

57. Kumar D, Nath L, Kamal MA, Varshney A, Jain A, Singh S, et al. Genome-wide analysis of the host intracellular network that regulates survival of Mycobacterium tuberculosis. Cell (2010) 140:731-43. doi:10.1016/j.cell.2010.02.012

58. Mueller P, Liu X, Pieters J. Migration and homeostasis of naive T cells depends on coronin 1-mediated prosurvival signals and not on coronin 1dependent filamentous actin modulation. J Immunol (2011) 186:4039-50. doi:10.4049/jimmunol.1003352

59. Pieters J, Muller P, Jayachandran R. On guard: coronin proteins in innate and adaptive immunity. Nat Rev Immunol (2013) 13:510-8. doi:10.1038/nri3465

60. Deghmane AE, Soualhine $\mathrm{H}$, Bach H, Sendide K, Itoh S, Tam A, et al. Lipoamide dehydrogenase mediates retention of coronin-1 on BCG vacuoles, leading to arrest in phagosome maturation. J Cell Sci (2007) 120:2796-806. doi: $10.1242 /$ jcs. 022335

61. Venugopal A, Bryk R, Shi S, Rhee K, Rath P, Schnappinger D, et al. Virulence of Mycobacterium tuberculosis depends on lipoamide dehydrogenase, a member of three multienzyme complexes. Cell Host Microbe (2011) 9:21-31. doi:10.1016/j.chom.2010.12.004

62. Pieters J, McKinney JD, editors. Pathogenesis of Mycobacterium Tuberculosis. Berlin: Springer Verlag (2013).

63. Foger N, Rangell L, Danilenko DM, Chan AC. Requirement for coronin 1 in T lymphocyte trafficking and cellular homeostasis. Science (2006) 313:839-42. doi:10.1126/science. 1130563
64. Shiow LR, Roadcap DW, Paris K, Watson SR, Grigorova IL, Lebet T, et al. The actin regulator coronin $1 \mathrm{~A}$ is mutant in a thymic egress-deficient mouse strain and in a patient with severe combined immunodeficiency. Nat Immunol (2008) 9:1307-15. doi:10.1038/ni.1662

65. Fratti RA, Backer JM, Gruenberg J, Corvera S, Deretic V. Role of phosphatidylinositol 3-kinase and Rab5 effectors in phagosomal biogenesis and mycobacterial phagosome maturation arrest. J Cell Biol (2001) 154:631-44. doi:10.1083/jcb.200106049

66. Bach H, Papavinasasundaram KG, Wong D, Hmama Z, Av-Gay Y. Mycobacterium tuberculosis virulence is mediated by PtpA dephosphorylation of human vacuolar protein sorting 33B. Cell Host Microbe (2008) 3:316-22. doi:10.1016/j.chom.2008.03.008

67. Berthet FX, Lagranderie M, Gounon P, Laurent-Winter C, Ensergueix D, Chavarot P, et al. Attenuation of virulence by disruption of the Mycobacterium tuberculosis erp gene. Science (1998) 282:759-62. doi:10.1126/science. 282.5389 .759

68. de Mendonca-Lima L, Picardeau M, Raynaud C, Rauzier J, de la Salmoniere YO, Barker L, et al. Erp, an extracellular protein family specific to mycobacteria. Microbiology (2001) 147:2315-20.

69. Klepp LI, Soria M, Blanco FC, Bianco MV, Santangelo MP, Cataldi AA, et al. Identification of two proteins that interact with the Erp virulence factor from Mycobacterium tuberculosis by using the bacterial two-hybrid system. BMCMol Biol (2009) 10:3. doi:10.1186/1471-2199-10-3

70. Walburger A, Koul A, Ferrari G, Nguyen L, Prescianotto-Baschong C, Huygen $\mathrm{K}$, et al. Protein kinase $\mathrm{G}$ from pathogenic mycobacteria promotes survival within macrophages. Science (2004) 304:1800-4. doi:10.1126/science. 1099384

71. Houben EN, Walburger A, Ferrari G, Nguyen L, Thompson CJ, Miess C, et al. Differential expression of a virulence factor in pathogenic and nonpathogenic mycobacteria. Mol Microbiol (2009) 72:41-52. doi:10.1111/j.13652958.2009.06612.x

72. Cowley S, Ko M, Pick N, Chow R, Downing KJ, Gordhan BG, et al. The Mycobacterium tuberculosis protein serine/threonine kinase $\mathrm{PknG}$ is linked to cellular glutamate/glutamine levels and is important for growth in vivo. Mol Microbiol (2004) 52:1691-702. doi:10.1111/j.1365-2958.2004.04085.x

73. Scherr N, Honnappa S, Kunz G, Mueller P, Jayachandran R, Winkler F, et al. From the cover: structural basis for the specific inhibition of protein kinase G, a virulence factor of Mycobacterium tuberculosis. Proc Natl Acad Sci U S A (2007) 104:12151-6. doi:10.1073/pnas.0702842104

74. Jayachandran R, Scherr N, Pieters J. Analyzing the interaction of pathogens with the host immune system. Immunol Lett (2009) 122:112-4. doi:10.1016/j. imlet.2008.11.016

75. Scherr N, Pieters J. The eukaryotic-like serine/threonine protein kinase family in mycobacteria. In: Parish T, Brown A, editors. Mycobacterium: Genomics and Molecular Biology. Norfolk, UK: Horizon Scientific Press (2009). p. 171-88.

76. Warner DF, Mizrahi V. The survival kit of Mycobacterium tuberculosis. Nat Med (2007) 13:282-4. doi:10.1038/nm0307-282

77. Janssen S, Jayachandran R, Khathi L, Zinsstag J, Grobusch MP, Pieters J. Exploring prospects of novel drugs for tuberculosis. Drug Des Devel Ther (2012) 6:217-24. doi:10.2147/DDDT.S34006

78. Saleh MT, Belisle JT. Secretion of an acid phosphatase (SapM) by Mycobacterium tuberculosis that is similar to eukaryotic acid phosphatases. J Bacteriol (2000) 182:6850-3. doi:10.1128/JB.182.23.6850-6853.2000

79. Vergne I, Chua J, Lee HH, Lucas M, Belisle J, Deretic V. Mechanism of phagolysosome biogenesis block by viable Mycobacterium tuberculosis. Proc Natl Acad Sci U S A (2005) 102:4033-8. doi:10.1073/pnas.0409716102

80. Martinon F, Burns K, Tschopp J. The inflammasome: a molecular platform triggering activation of inflammatory caspases and processing of proIL-beta. Mol Cell (2002) 10:417-26. doi:10.1016/S1097-2765(02)00599-3

81. Gross O, Thomas CJ, Guarda G, Tschopp J. The inflammasome: an integrated view. Immunol Rev (2011) 243:136-51. doi:10.1111/j.1600-065X.2011.01046.x

82. Master SS, Rampini SK, Davis AS, Keller C, Ehlers S, Springer B, et al. Mycobacterium tuberculosis prevents inflammasome activation. Cell Host Microbe (2008) 3:224-32. doi:10.1016/j.chom.2008.03.003

83. Kim KH, An DR, Song J, Yoon JY, Kim HS, Yoon HJ, et al. Mycobacterium tuberculosis Eis protein initiates suppression of host immune responses by acetylation of DUSP16/MKP-7. Proc Natl Acad Sci U S A (2012) 109:7729-34. doi:10.1073/pnas.1120251109 
84. Shin DM, Jeon BY, Lee HM, Jin HS, Yuk JM, Song CH, et al. Mycobacterium tuberculosis eis regulates autophagy, inflammation, and cell death through redox-dependent signaling. PLoS Pathog (2010) 6:e1001230. doi:10.1371/ journal.ppat. 1001230

85. Hsu T, Hingley-Wilson SM, Chen B, Chen M, Dai AZ, Morin PM, et al. The primary mechanism of attenuation of bacillus Calmette-Guerin is a loss of secreted lytic function required for invasion of lung interstitial tissue. Proc Natl Acad Sci U S A (2003) 100:12420-5. doi:10.1073/pnas.1635213100

86. Gao LY, Guo S, McLaughlin B, Morisaki H, Engel JN, Brown EJ. A mycobacterial virulence gene cluster extending RD1 is required for cytolysis, bacterial spreading and ESAT-6 secretion. Mol Microbiol (2004) 53:1677-93. doi:10.1111/j.1365-2958.2004.04261.x

87. Abdallah AM, Gey Van Pittius NC, Champion PA, Cox J, Luirink J, Vandenbroucke-Grauls CM, et al. Type VII secretion - mycobacteria show the way. Nat Rev Microbiol (2007) 5:883-91. doi:10.1038/nrmicro1773

88. Digiuseppe Champion PA, Cox JS. Protein secretion systems in mycobacteria. Cell Microbiol (2007) 9:1376-84. doi:10.1111/j.1462-5822.2007.00943.x

89. Brodin P, Rosenkrands I, Andersen P, Cole ST, Brosch R. ESAT-6 proteins: protective antigens and virulence factors? Trends Microbiol (2004) 12:500-8. doi:10.1016/j.tim.2004.09.007

90. de Jonge MI, Pehau-Arnaudet G, Fretz MM, Romain F, Bottai D, Brodin P, et al. ESAT-6 from Mycobacterium tuberculosis dissociates from its putative chaperone CFP-10 under acidic conditions and exhibits membrane-lysing activity. J Bacteriol (2007) 189:6028-34. doi:10.1128/JB.00469-07

91. van der Wel N, Hava D, Houben D, Fluitsma D, Van Zon M, Pierson J, et al. $M$. tuberculosis and $M$. leprae translocate from the phagolysosome to the cytosol in myeloid cells. Cell (2007) 129:1287-98. doi:10.1016/j.cell.2007.05.059

92. Chen JM, Boy-Rottger S, Dhar N, Sweeney N, Buxton RS, Pojer F, et al. EspD is critical for the virulence-mediating ESX-1 secretion system in Mycobacterium tuberculosis. J Bacteriol (2012) 194:884-93. doi:10.1128/JB.06417-11

93. Hart PD. Critical approach to the technique of assessment of antibacterial effects of activated mouse peritoneal macrophages. In: Wagner WH, Hahn H, editors. Activation of Macrophages. Amsterdam: Excerpta Medica (1974). 131 p.

94. North RJ. T cell dependence of macrophage activation and mobilization during infection with Mycobacterium tuberculosis. Infect Immun (1974) 10:66-71.

95. Nathan CF, Tsunawaki S. Secretion of toxic oxygen products by macrophages: regulatory cytokines and their effects on the oxidase. Ciba Found Symp (1986) 118:211-30.

96. Flynn JL, Chan J, Triebold KJ, Dalton DK, Stewart TA, Bloom BR. An essential role for interferon gamma in resistance to Mycobacterium tuberculosis infection. J Exp Med (1993) 178:2249-54. doi:10.1084/jem.178.6.2249

97. Gordon S, Keshav S, Stein M. BCG-induced granuloma formation in murine tissues. Immunobiology (1994) 191:369-77. doi:10.1016/S0171-2985(11) 80442-0

98. Armstrong JA, Hart PD. Response of cultured macrophages to Mycobacterium tuberculosis, with observations on fusion of lysosomes with phagosomes. J Exp Med (1971) 134:713-40. doi:10.1084/jem.134.3.713

99. Flynn JL, Chan J. Immunology of tuberculosis. Annu Rev Immunol (2001) 19:93-129. doi:10.1146/annurev.immunol.19.1.93

100. Vidal SM, Malo D, Vogan K, Skamene E, Gros P. Natural resistance to infection with intracellular parasites: isolation of a candidate for Bcg. Cell (1993) 73:469-85. doi:10.1016/0092-8674(93)90135-D

101. Supek F, Supekova L, Nelson H, Nelson N. A yeast manganese transporter related to the macrophage protein involved in conferring resistance to mycobacteria. Proc Natl Acad Sci U S A (1996) 93:5105-10. doi:10.1073/pnas. 93.10.5105

102. Hackam DJ, Rotstein OD, Zhang W, Gruenheid S, Gros P, Grinstein S. Host resistance to intracellular infection: mutation of natural resistance-associated macrophage protein 1 (Nramp1) impairs phagosomal acidification. J Exp Med (1998) 188:351-64. doi:10.1084/jem.188.2.351

103. Jabado N, Jankowski A, Dougaparsad S, Picard V, Grinstein S, Gros P. Natural resistance to intracellular infections: natural resistance-associated macrophage protein 1 (Nrampl) functions as a $\mathrm{pH}$-dependent manganese transporter at the phagosomal membrane. J Exp Med (2000) 192:1237-48. doi:10.1084/jem.192.9.1237

104. Searle S, Bright NA, Roach TI, Atkinson PG, Barton CH, Meloen RH, et al. Localisation of Nramp1 in macrophages: modulation with activation and infection. J Cell Sci (1998) 111(Pt 19):2855-66.
105. Skamene E. The Bcg gene story. Immunobiology (1994) 191:451-60. doi:10. 1016/S0171-2985(11)80451-1

106. Govoni G, Gros P. Macrophage NRAMP1 and its role in resistance to microbial infections. Inflamm Res (1998) 47:277-84. doi:10.1007/s000110050330

107. Bosedasgupta S, Pieters J. Inflammatory stimuli reprogram macrophage phagocytosis to macropinocytosis for the rapid elimination of pathogens. PLoS Pathog (2014) 10:e1003879. doi:10.1371/journal.ppat.1003879

108. Swanson JA, Watts C. Macropinocytosis. Trends Cell Biol (1995) 5:424-8. doi:10.1016/S0962-8924(00)89101-1

109. Araki N, Johnson MT, Swanson JA. A role for phosphoinositide 3-kinase in the completion of macropinocytosis and phagocytosis by macrophages. J Cell Biol (1996) 135:1249-60. doi:10.1083/jcb.135.5.1249

110. Swanson JA. Shaping cups into phagosomes and macropinosomes. Nat Rev Mol Cell Biol (2008) 9:639-49. doi:10.1038/nrm2447

111. Boehm U, Klamp T, Groot M, Howard JC. Cellular responses to interferongamma. Annu Rev Immunol (1997) 15:749-95. doi:10.1146/annurev.immunol. 15.1.749

112. Feng CG, Zheng L, Lenardo MJ, Sher A. Interferon-inducible immunity-related GTPase Irgm1 regulates IFN gamma-dependent host defense, lymphocyte survival and autophagy. Autophagy (2009) 5:232-4. doi:10.4161/auto.5.2.7445

113. Dupont CD, Hunter CA. Guanylate-binding proteins: niche recruiters for antimicrobial effectors. Immunity (2012) 37:191-3. doi:10.1016/j.immuni. 2012.08.005

114. Boehm U, Guethlein L, Klamp T, Ozbek K, Schaub A, Futterer A, et al. Two families of GTPases dominate the complex cellular response to IFN-gamma. J Immunol (1998) 161:6715-23.

115. MacMicking JD, Taylor GA, McKinney JD. Immune control of tuberculosis by IFN-gamma-inducible LRG-47. Science (2003) 302:654-9. doi:10.1126/ science. 1088063

116. Hunn JP, Feng CG, Sher A, Howard JC. The immunity-related GTPases in mammals: a fast-evolving cell-autonomous resistance system against intracellular pathogens. Mamm Genome (2011) 22:43-54. doi:10.1007/s00335010-9293-3

117. Kim BH, Shenoy AR, Kumar P, Das R, Tiwari S, MacMicking JD. A family of IFN-gamma-inducible $65-\mathrm{kD}$ GTPases protects against bacterial infection. Science (2011) 332:717-21. doi:10.1126/science.1201711

118. Matsuzawa T, Kim BH, Shenoy AR, Kamitani S, Miyake M, MacMicking JD. IFN-gamma elicits macrophage autophagy via the p38 MAPK signaling pathway. J Immunol (2012) 189:813-8. doi:10.4049/jimmunol.1102041

119. Springer HM, Schramm M, Taylor GA, Howard JC. Irgm1 (LRG-47), a regulator of cell-autonomous immunity, does not localize to mycobacterial or listerial phagosomes in IFN-gamma-induced mouse cells. J Immunol (2013) 191:1765-74. doi:10.4049/jimmunol.1300641

120. Feng CG, Collazo-Custodio CM, Eckhaus M, Hieny S, Belkaid Y, Elkins K, et al. Mice deficient in LRG-47 display increased susceptibility to mycobacterial infection associated with the induction of lymphopenia. J Immunol (2004) 172:1163-8. doi:10.4049/jimmunol.172.2.1163

121. Santiago HC, Feng CG, Bafica A, Roffe E, Arantes RM, Cheever A, et al. Mice deficient in LRG-47 display enhanced susceptibility to Trypanosoma cruzi infection associated with defective hemopoiesis and intracellular control of parasite growth. J Immunol (2005) 175:8165-72. doi:10.4049/jimmunol.175. 12.8165

122. Henry SC, Daniell X, Indaram M, Whitesides JF, Sempowski GD, Howell $D$, et al. Impaired macrophage function underscores susceptibility to Salmonella in mice lacking Irgm1 (LRG-47). J Immunol (2007) 179:6963-72. doi:10.4049/jimmunol.179.10.6963

123. Feng CG, Weksberg DC, Taylor GA, Sher A, Goodell MA. The p47 GTPase Lrg-47 (Irgm1) links host defense and hematopoietic stem cell proliferation. Cell Stem Cell (2008) 2:83-9. doi:10.1016/j.stem.2007.10.007

124. Nathan C, Shiloh MU. Reactive oxygen and nitrogen intermediates in the relationship between mammalian hosts and microbial pathogens. Proc Natl Acad Sci U S A (2000) 97:8841-8. doi:10.1073/pnas.97.16.8841

125. Ehrt S, Schnappinger D. Mycobacterial survival strategies in the phagosome: defence against host stresses. Cell Microbiol (2009) 11:1170-8. doi:10.1111/j. 1462-5822.2009.01335.x

126. Vilcheze C, Hartman T, Weinrick B, Jacobs WR Jr. Mycobacterium tuberculosis is extraordinarily sensitive to killing by a vitamin C-induced Fenton reaction. Nat Commun (2013) 4:1881. doi:10.1038/ncomms 2898 
127. Nathan C. Role of iNOS in human host defense. Science (2006) 312:1874-5; author reply 1874-75. doi:10.1126/science.312.5782.1874b

128. Mishra BB, Rathinam VA, Martens GW, Martinot AJ, Kornfeld H, Fitzgerald KA, et al. Nitric oxide controls the immunopathology of tuberculosis by inhibiting NLRP3 inflammasome-dependent processing of IL-1beta. Nat Immunol (2013) 14:52-60. doi:10.1038/ni.2474

129. Mattila JT, Ojo OO, Kepka-Lenhart D, Marino S, Kim JH, Eum SY, et al. Microenvironments in tuberculous granulomas are delineated by distinct populations of macrophage subsets and expression of nitric oxide synthase and arginase isoforms. J Immunol (2013) 191:773-84. doi:10.4049/jimmunol. 1300113

130. Darwin KH, Ehrt S, Gutierrez-Ramos JC, Weich N, Nathan CF. The proteasome of Mycobacterium tuberculosis is required for resistance to nitric oxide. Science (2003) 302:1963-6. doi:10.1126/science.1091176

131. Pieters J, Ploegh H. Microbiology. Chemical warfare and mycobacterial defense. Science (2003) 302:1900-2. doi:10.1126/science.1092873

132. Lin G, Li D, De Carvalho LP, Deng H, Tao H, Vogt G, et al. Inhibitors selective for mycobacterial versus human proteasomes. Nature (2009) 461:621-6. doi:10.1038/nature08357

133. Gutierrez MG, Master SS, Singh SB, Taylor GA, Colombo MI, Deretic V. Autophagy is a defense mechanism inhibiting BCG and Mycobacterium tuberculosis survival in infected macrophages. Cell (2004) 119:753-66. doi:10.1016/ j.cell.2004.11.038

134. Gomes LC, Dikic I. Autophagy in antimicrobial immunity. Mol Cell (2014) 54:224-33. doi:10.1016/j.molcel.2014.03.009

135. Manzanillo PS, Ayres JS, Watson RO, Collins AC, Souza G, Rae CS, et al. The ubiquitin ligase parkin mediates resistance to intracellular pathogens. Nature (2013) 501:512-6. doi:10.1038/nature12566

136. Ehlers S, Schaible UE. The granuloma in tuberculosis: dynamics of a host-pathogen collusion. Front Immunol (2012) 3:411. doi:10.3389/fimmu. 2012.00411

137. Gordon S. Alternative activation of macrophages. Nat Rev Immunol (2003) 3:23-35. doi:10.1038/nri978

138. Russell DG, Cardona PJ, Kim MJ, Allain S, Altare F. Foamy macrophages and the progression of the human tuberculosis granuloma. Nat Immunol (2009) 10:943-8. doi:10.1038/ni.1781

139. Egen JG, Rothfuchs AG, Feng CG, Horwitz MA, Sher A, Germain RN. Intravital imaging reveals limited antigen presentation and $\mathrm{T}$ cell effector function in mycobacterial granulomas. Immunity (2011) 34:807-19. doi:10.1016/j. immuni.2011.03.022

140. Bartlett JG. Tuberculosis and HIV infection: partners in human tragedy. J Infect Dis (2007) 196(Suppl 1):S124-5. doi:10.1086/518668

141. Wallis RS, Broder M, Wong J, Lee A, Hoq L. Reactivation of latent granulomatous infections by infliximab. Clin Infect Dis (2005) 41(Suppl 3):S194-8. doi:10.1086/429996

142. Fallahi-Sichani M, Flynn JL, Linderman JJ, Kirschner DE. Differential risk of tuberculosis reactivation among anti-TNF therapies is due to drug binding kinetics and permeability. J Immunol (2012) 188:3169-78. doi:10.4049/ jimmunol.1103298

143. Adib-Conquy M, Scott-Algara D, Cavaillon JM, Souza-Fonseca-Guimaraes F. TLR-mediated activation of NK cells and their role in bacterial/viral immune responses in mammals. Immunol Cell Biol (2014) 92:256-62. doi: 10.1038/icb.2013.99

144. Cougoule C, Constant P, Etienne G, Daffe M, Maridonneau-Parini I. Lack of fusion of azurophil granules with phagosomes during phagocytosis of Mycobacterium smegmatis by human neutrophils is not actively controlled by the bacterium. Infect Immun (2002) 70:1591-8. doi:10.1128/IAI.70.3.15911598.2002

145. Martineau AR, Newton SM, Wilkinson KA, Kampmann B, Hall BM, Nawroly $\mathrm{N}$, et al. Neutrophil-mediated innate immune resistance to mycobacteria. JClin Invest (2007) 117:1988-94. doi:10.1172/JCI31097

146. Cruz DN, De Cal M, Garzotto F, Perazella MA, Lentini P, Corradi V, et al. Plasma neutrophil gelatinase-associated lipocalin is an early biomarker for acute kidney injury in an adult ICU population. Intensive Care Med (2010) 36:444-51. doi:10.1007/s00134-009-1711-1

147. Brill KJ, Li Q, Larkin R, Canaday DH, Kaplan DR, Boom WH, et al. Human natural killer cells mediate killing of intracellular Mycobacterium tuberculosis $\mathrm{H} 37 \mathrm{Rv}$ via granule-independent mechanisms. Infect Immun (2001) 69:1755-65. doi:10.1128/IAI.69.3.1755-1765.2001
148. Bermudez LE, Young LS. Natural killer cell-dependent mycobacteriostatic and mycobactericidal activity in human macrophages. J Immunol (1991) 146:265-70.

149. Newman KC, Riley EM. Whatever turns you on: accessory-cell-dependent activation of NK cells by pathogens. Nat Rev Immunol (2007) 7:279-91. doi:10.1038/nri2057

150. Harding CV, Collins DS, Slot JW, Geuze HJ, Unanue ER. Liposomeencapsulated antigens are processed in lysosomes, recycled, and presented to $\mathrm{T}$ cells. Cell (1991) 64:393-401. doi:10.1016/0092-8674(91)90647-H

151. Tulp A, Verwoerd D, Dobberstein B, Ploegh HL, Pieters J. Isolation and characterization of the intracellular MHC class II compartment. Nature (1994) 369:120-6. doi:10.1038/369120a0

152. Wolf PR, Ploegh HL. How MHC class II molecules acquire peptide cargo: biosynthesis and trafficking through the endocytic pathway. Annu Rev Cell Dev Biol (1995) 11:267-306. doi:10.1146/annurev.cb.11.110195.001411

153. Caruso AM, Serbina N, Klein E, Triebold K, Bloom BR, Flynn JL. Mice deficient in CD4 T cells have only transiently diminished levels of IFN-gamma, yet succumb to tuberculosis. I Immunol (1999) 162:5407-16.

154. Gallegos AM, Pamer EG, Glickman MS. Delayed protection by ESAT-6-specific effector CD4+ T cells after airborne M. tuberculosis infection. J Exp Med (2008) 205:2359-68. doi:10.1084/jem.20080353

155. Geldmacher C, Ngwenyama N, Schuetz A, Petrovas C, Reither K, Heeregrave EJ, et al. Preferential infection and depletion of Mycobacterium tuberculosisspecific CD4 T cells after HIV-1 infection. J Exp Med (2010) 207:2869-81. doi:10.1084/jem.20100090

156. Ackerman AL, Kyritsis C, Tampe R, Cresswell P. Early phagosomes in dendritic cells form a cellular compartment sufficient for cross presentation of exogenous antigens. Proc Natl Acad Sci U S A (2003) 100:12889-94. doi:10.1073/pnas.1735556100

157. Guermonprez P, Saveanu L, Kleijmeer M, Davoust J, Van Endert P, Amigorena S. ER-phagosome fusion defines an MHC class I cross-presentation compartment in dendritic cells. Nature (2003) 425:397-402. doi:10.1038/nature01911

158. Sud D, Bigbee C, Flynn JL, Kirschner DE. Contribution of CD8+ T cells to control of Mycobacterium tuberculosis infection. J Immunol (2006) 176:4296-314. doi:10.4049/jimmunol.176.7.4296

159. Weerdenburg EM, Peters PJ, van der Wel NN. How do mycobacteria activate CD8+ T cells? Trends Microbiol (2010) 18:1-10. doi:10.1016/j.tim.2009. 10.004

160. Stenger S, Hanson DA, Teitelbaum R, Dewan P, Niazi KR, Froelich CJ, et al. An antimicrobial activity of cytolytic T cells mediated by granulysin. Science (1998) 282:121-5. doi:10.1126/science.282.5386.121

161. Pardoll DM, Kruisbeek AM, Fowlkes BJ, Coligan JE, Schwartz RH. The unfolding story of T cell receptor gamma. FASEB J (1987) 1:103-9.

162. Raulet DH. The structure, function, and molecular genetics of the gamma/delta T cell receptor. Annu Rev Immunol (1989) 7:175-207. doi:10.1146/annurev.iy. 07.040189 .001135

163. Gertner J, Wiedemann A, Poupot M, Fournie JJ. Human gammadelta T lymphocytes strip and kill tumor cells simultaneously. Immunol Lett (2007) 110:42-53. doi:10.1016/j.imlet.2007.03.002

164. Mori L, De Libero G. T cells specific for lipid antigens. Immunol Res (2012) 53:191-9. doi:10.1007/s12026-012-8294-6

165. de la Salle H, Hanau D, Fricker D, Urlacher A, Kelly A, Salamero J, et al. Homozygous human TAP peptide transporter mutation in HLA class I deficiency. Science (1994) 265:237-41. doi:10.1126/science.7517574

166. Rojas RE, Chervenak KA, Thomas J, Morrow J, Nshuti L, Zalwango S, et al. Vdelta2+ gammadelta T cell function in Mycobacterium tuberculosis- and HIV1-positive patients in the United States and Uganda: application of a wholeblood assay. J Infect Dis (2005) 192:1806-14. doi:10.1086/497146

167. Mori L, De Libero G. Presentation of lipid antigens to T cells. Immunol Lett (2008) 117:1-8. doi:10.1016/j.imlet.2007.11.027

168. McGill JL, Sacco RE, Baldwin CL, Telfer JC, Palmer MV, Waters WR. Specific recognition of mycobacterial protein and peptide antigens by gammadelta $\mathrm{T}$ cell subsets following infection with virulent Mycobacterium bovis. J Immunol (2014) 192:2756-69. doi:10.4049/jimmunol.1302567

169. Herbst S, Schaible UE, Schneider BE. Interferon gamma activated macrophages kill mycobacteria by nitric oxide induced apoptosis. PLoS One (2011) 6:e19105 doi:10.1371/journal.pone.0019105

170. Stark GR, Kerr IM, Williams BR, Silverman RH, Schreiber RD. How cells respond to interferons. Annu Rev Biochem (1998) 67:227-64. 
171. Feng CG, Bean AG, Hooi H, Briscoe H, Britton WJ. Increase in gamma interferon-secreting $\mathrm{CD} 8(+)$, as well as $\mathrm{CD} 4(+)$, T cells in lungs following aerosol infection with Mycobacterium tuberculosis. Infect Immun (1999) 67:3242-7.

172. Stanley SA, Cox JS. Host-pathogen interactions during Mycobacterium tuberculosis infections. Curr Top Microbiol Immunol (2013) 374:211-41. doi:10.1007/ 82_2013_332

173. Jouanguy E, Lamhamedi-Cherradi S, Altare F, Fondaneche MC, Tuerlinckx D, Blanche S, et al. Partial interferon-gamma receptor 1 deficiency in a child with tuberculoid bacillus Calmette-Guerin infection and a sibling with clinical tuberculosis. J Clin Invest (1997) 100:2658-64. doi:10.1172/ JCI119810

174. Jouanguy E, Doffinger R, Dupuis S, Pallier A, Altare F, Casanova JL. IL-12 and IFN-gamma in host defense against mycobacteria and Salmonella in mice and men. Curr Opin Immunol (1999) 11:346-51. doi:10.1016/S0952-7915(99) 80055-7

175. Seneviratne SL, Doffinger R, Macfarlane J, Ceron-Gutierrez L, Amel Kashipaz MR, Robbins A, et al. Disseminated Mycobacterium tuberculosis infection due to interferon gamma deficiency. Response to replacement therapy. Thorax (2007) 62:97-9. doi:10.1136/thx.2005.051649

176. Flynn JL, Goldstein MM, Chan J, Triebold KJ, Pfeffer K, Lowenstein CJ, et al. Tumor necrosis factor-alpha is required in the protective immune response against Mycobacterium tuberculosis in mice. Immunity (1995) 2:561-72. doi: 10.1016/1074-7613(95)90001-2

177. Quesniaux VF, Jacobs M, Allie N, Grivennikov S, Nedospasov SA, Garcia I, et al. TNF in host resistance to tuberculosis infection. Curr Dir Autoimmun (2010) 11:157-79. doi:10.1159/000289204

178. Roca FJ, Ramakrishnan L. TNF dually mediates resistance and susceptibility to mycobacteria via mitochondrial reactive oxygen species. Cell (2013) 153:521-34. doi:10.1016/j.cell.2013.03.022

179. Millington KA, Gooding S, Hinks TS, Reynolds DJ, Lalvani A. Mycobacterium tuberculosis-specific cellular immune profiles suggest bacillary persistence decades after spontaneous cure in untreated tuberculosis. J Infect Dis (2010) 202:1685-9. doi:10.1086/656772

180. Al-Attiyah R, El-Shazly A, Mustafa AS. Comparative analysis of spontaneous and mycobacterial antigen-induced secretion of Th1, Th2 and proinflammatory cytokines by peripheral blood mononuclear cells of tuberculosis patients. Scand J Immunol (2012) 75:623-32. doi:10.1111/j.1365-3083.2012. 02692.x

181. Fulton SA, Johnsen JM, Wolf SF, Sieburth DS, Boom WH. Interleukin-12 production by human monocytes infected with Mycobacterium tuberculosis: role of phagocytosis. Infect Immun (1996) 64:2523-31.

182. de Jong R, Altare F, Haagen IA, Elferink DG, Boer T, Van Breda Vriesman PJ, et al. Severe mycobacterial and Salmonella infections in interleukin-12 receptor-deficient patients. Science (1998) 280:1435-8. doi:10.1126/science. 280.5368.1435

183. Taha RA, Minshall EM, Olivenstein R, Ihaku D, Wallaert B, Tsicopoulos A, et al. Increased expression of IL-12 receptor mRNA in active pulmonary tuberculosis and sarcoidosis. Am J Respir Crit Care Med (1999) 160:1119-23. doi:10.1164/ajrccm.160.4.9807120

184. Cooper AM, Solache A, Khader SA. Interleukin-12 and tuberculosis: an old story revisited. Curr Opin Immunol (2007) 19:441-7. doi:10.1016/j.coi.2007. 07.004

185. Robinson CM, Nau GJ. Interleukin-12 and interleukin-27 regulate macrophage control of Mycobacterium tuberculosis. J Infect Dis (2008) 198:359-66. doi:10. $1086 / 589774$

186. Castillo-Velazquez U, Aranday-Cortes E, Gutierrez-Pabello JA. Alternative activation modifies macrophage resistance to Mycobacterium bovis. Vet Microbiol (2011) 151:51-9. doi:10.1016/j.vetmic.2011.02.025

187. Lukacs NW, Addison CL, Gauldie J, Graham F, Simpson K, Strieter RM, et al. Transgene-induced production of IL- 4 alters the development and collagen expression of T helper cell 1-type pulmonary granulomas. J Immunol (1997) 158:4478-84.

188. van Crevel R, Ottenhoff TH, van der Meer JW. Innate immunity to Mycobacterium tuberculosis. Clin Microbiol Rev (2002) 15:294-309. doi:10.1128/CMR. 15.2.294-309.2002

189. Dahl KE, Shiratsuchi H, Hamilton BD, Ellner JJ, Toossi Z. Selective induction of transforming growth factor beta in human monocytes by lipoarabinomannan of Mycobacterium tuberculosis. Infect Immun (1996) 64:399-405.

190. Chan J, Fan XD, Hunter SW, Brennan PJ, Bloom BR. Lipoarabinomannan, a possible virulence factor involved in persistence of Mycobacterium tuberculosis within macrophages. Infect Immun (1991) 59:1755-61.

191. Gong JH, Zhang M, Modlin RL, Linsley PS, Iyer D, Lin Y, et al. Interleukin-10 downregulates Mycobacterium tuberculosis-induced Th1 responses and CTLA4 expression. Infect Immun (1996) 64:913-8.

192. Fulton SA, Cross JV, Toossi ZT, Boom WH. Regulation of interleukin-12 by interleukin-10, transforming growth factor-beta, tumor necrosis factor-alpha, and interferon-gamma in human monocytes infected with Mycobacterium tuberculosis H37Ra. J Infect Dis (1998) 178:1105-14. doi:10.1086/515698

193. Hirsch CS, Toossi Z, Othieno C, Johnson JL, Schwander SK, Robertson S, et al. Depressed T-cell interferon-gamma responses in pulmonary tuberculosis: analysis of underlying mechanisms and modulation with therapy. J Infect Dis (1999) 180:2069-73. doi:10.1086/315114

194. Knutson KL, Hmama Z, Herrera-Velit P, Rochford R, Reiner, NE. Lipoarabinomannan of Mycobacterium tuberculosis promotes protein tyrosine dephosphorylation and inhibition of mitogen-activated protein kinase in human mononuclear phagocytes. Role of the Src homology 2 containing tyrosine phosphatase 1. J Biol Chem (1998) 273:645-52. doi:10.1074/jbc.273.1.645

195. Murray PJ, Wang L, Onufryk C, Tepper RI, Young RA. T cell-derived IL10 antagonizes macrophage function in mycobacterial infection. J Immunol (1997) 158:315-21.

196. Khalil N, Bereznay O, Sporn M, Greenberg AH. Macrophage production of transforming growth factor beta and fibroblast collagen synthesis in chronic pulmonary inflammation. J Exp Med (1989) 170:727-37. doi:10.1084/jem.170. 3.727

197. Othieno C, Hirsch CS, Hamilton BD, Wilkinson K, Ellner JJ, Toossi Z. Interaction of Mycobacterium tuberculosis-induced transforming growth factor betal and interleukin-10. Infect Immun (1999) 67:5730-5.

198. Mosser DM. The many faces of macrophage activation. J Leukoc Biol (2003) 73:209-12. doi:10.1189/jlb.0602325

199. Guo S, Zhao J. Immunotherapy for tuberculosis: what's the better choice? Front Biosci (Landmark Ed) (2012) 17:2684-90. doi:10.2741/4079

200. Luzina IG, Keegan AD, Heller NM, Rook GA, Shea-Donohue T, Atamas SP. Regulation of inflammation by interleukin-4: a review of "alternatives". J Leukoc Biol (2012) 92:753-64. doi:10.1189/jlb.0412214

Conflict of Interest Statement: The authors declare that the research was conducted in the absence of any commercial or financial relationships that could be construed as a potential conflict of interest.

Received: 28 May 2014; accepted: 06 September 2014; published online: 08 October 2014

Citation: BoseDasgupta S and Pieters J (2014) Striking the right balance determines TB or not TB. Front. Immunol. 5:455. doi: 10.3389/fimmu.2014.00455

This article was submitted to Microbial Immunology, a section of the journal Frontiers in Immunology.

Copyright (C) 2014 BoseDasgupta and Pieters. This is an open-access article distributed under the terms of the Creative Commons Attribution License (CC BY). The use, distribution or reproduction in other forums is permitted, provided the original author(s) or licensor are credited and that the original publication in this journal is cited, in accordance with accepted academic practice. No use, distribution or reproduction is permitted which does not comply with these terms. 